\title{
CHANGES IN THE COMPOSITION OF THE PULP, ALPHA-AMYLASE ACTIVITY AND TITRATABLE ACIDITY DURING THE CONTROLLED ROTTING OF EGUSI FRUITS (COLOCYNTHIS CITRULLUS L.) FOR THE HARVESTING OF THE SEEDS
}

\author{
C. ABRIBA AND J. A. N. OBETA \\ (Received 17 November 2009; Revision Accepted 23, February 2010)
}

\begin{abstract}
The laboratory rotting of Egusi Fruits was completed in 120 hours. At this stage pulp became soft and the seeds were extracted easily with the fingers. The changes in the composition of the pulp, alpha-amylase activity and titratable acidity during the controlled rotting of egusi fruit (Colocynthis citrullus L.) for the harvesting of the seeds showed that moisture content (MC) increased from $82.04 \%$ at 0 hour of rotting to $85.00 \%$ at 120 hours of rotting. The Titratable acidity increased from $0.10 \mathrm{mg}$ lactic acid/g, wet matter (WM) at 0 hour to $0.70 \mathrm{mg}$ lactic acid $/ \mathrm{g}$, at 120 hours. The total carbohydrate (water soluble carbohydrate) decreased from $10.76 \%$ at 0 hour to $0.35 \%$ at 120 hour and the reducing sugars also decreased from $1.25 \mathrm{mg} / \mathrm{g}(\mathrm{WM})$ at 0 hour to $0.25 \mathrm{mg} / \mathrm{g}(\mathrm{WM})$ at 120 hours; the protein content increased from $0.39 \%$ at 0 hour to $4.38 \%$ at 96 hours and then fell to $1.14 \%$ at 120 hours. The alpha-amylase activity which was not detectable at 0 hour reached a peak of $0.80 \mathrm{mg} / \mathrm{g}(\mathrm{WM})$ at 48 hours and then fell to $0.02 \mathrm{mg} / \mathrm{g}$ at 120 hours. The crude fat decreased from $6.85 \%$ at 0 hour to $6.72 \%$ at 120 hours. The pH rose from 5.20 at 0 hour to 6.70 at 120 hours while the temperature rose from $28.0^{\circ} \mathrm{C}$ at 0 hour to $30^{\circ} \mathrm{C}$ at 120 hours. These changes resulted in the softening of the pulp and hence facilitating the easy removal of the seeds from the fruits with fingers.
\end{abstract}

KEYWORDS: Rotting, Egusi, Pulp, Composition, Alpha-amylase, titratable acidity.

\section{INTRODUCTION}

Egusi (Colocynthis citrullus L.) is a creeping annual plant belongiong to the melon (Cucubitaceae) family. Many varieties are widely cultivated in the whole of West African sub-region including Nigeria, solely for their seeds. The fruit pulp has a bitter taste and the whole fruit is discarded after the extraction of the seeds. Egusi has been much confused with other members of the family especially water melon (Oyolu, 1977). He suggested the adoption of the common name egusi and the botanical name (Colocynthis citrullus) for all varieties of egusi to remove this confusion. However, the distinction between egusi melon and the popular water melon (Citrullus vulgaris schrad) whose fruit pulp is delicious has not been fully established. Some later works still refer to egusi seeds as water melon seeds (Odunfa, 1982, 1983 Achinewhu and Ryley, 1986).

The fruit is a melon type almost the size of cantaloupe (Akobundu et al. 1982), consisting relatively of hard outer covering and white inner fleshy pulp inside which numerous small flat seeds are embedded. The fruits are harvested when the vines and the leaves have dried up. They are cracked to expose the pulp to microbial attack by hitting with heavy objects. They are then packed in large heaps in the farm covered with foliage leaves and allowed to rot for 5-7 days. After rotting the pulp becomes soft and the seeds are easily extracted with fingers, washed and dried in the sun. The seeds are the only accurate method of measuring the yield (Oyolu, 1977), because the fruits contain mature and immature or incompletely filled seeds. Many studies have been documented on egusi namely: Microbiology of controlled rotting of egusi fruits (Colocynthis citrullus L.) for the harvesting of the seeds (Obeta and Abriba, 1994), biochemistry and nutritive value of the seeds (Oyenuga and Fatuga 1975), Chemical and nutritional composition of the seeds (Akobundu et al. 1982 Achinewhu, 1983 Obiora and King (1984), Onuorah and King (1984), and the feasibility of the use of melon seed protein as a baby food supplement (Strafford and Oke, 1977). Most of the work done so far, had been centered only on the seeds.

However, no work has been done on the changes in the composition of the pulp, alpha-amylase activity and titratable acidity during the rotting of the fruits, changes that are necessary for the harvesting of the seeds. The significance of the study is that the changes during rotting, resulted in the softening of the equsi pulp and therefore facilitating the easy removal of the seeds from the fruits with fingers.

\section{MATERIALS AND METHODS}

\section{Sample collection}

Seventy mature healthy egusi fruits of 'serewe' variety of various sizes were collected from farmers in Ogoja, Cross River State, Abakaliki in Ebonyi State, Enugu and Nsukka in Enugu State, Nigeria, in two batches of thirty-five (35) fruits each. They were washed with tap water immediately they were brought to the laboratory and stored in the refrigerator at $4^{0} \mathrm{C}$ for not more than 7 days before they were used in the experiment.

\section{LABORATORY ROTTING OF EGUSI FRUITS}

Rotting was carried out in three (3) batches,

C. Abriba, Department of Microbiology, University of Calabar, Calabar-Nigeria

J. A. N. Obeta, Department of Microbiology, University of Nigeria Nsukka, Nigeria. 
using fifteen (15) egusi fruits per batch. Four deep approximately equidistant cuts were made on each egusi fruits with a sharp sterile knife in such a manner that the parts were not allowed to fall apart. The cut parts usually became separated during sampling and they were held with clean elastic bands. Two uncut fruits were used as control for each batch. The fruits were heaped on a laboratory bench, covered with cellophane materials and allowed to rot at room temperature $\mathrm{C} \mathrm{Ca}$ $28^{\circ} \mathrm{C}$ ) until rotting was completed.

The degree in all the experiments was determined, subjectively by the ease with which the seeds could be removed from the pulp.

\section{ASSESSMENT OF THE CHANGES IN THE COMPOSITION OF THE PULP, ALPHA-AMYLASE ACTIVITY AND TITRATABLE ACIDITY DURING THE ROTTING OF EGUSI FRUITS TO HARVEST THE SEEDS}

The changes in the composition of the pulp, alpha-amylase activity and titratable acidity during the controlled rotting of egusi fruits were determined using healthy fruits as mentioned earlier. Pooled samples (daily) of the pulp were obtained from the fruits and used for the determination during the periods of rotting. Appropriate weights of the samples were used as per each determination.

Determination of moisture content (MC): The moisture content of the pulp was determined by the hot air oven method as described by the Association of Official Analytical Chemists (AOAC, 1990).

Determination of total Carbohydrate: The determination of the total carbohydrate was carried out by the phenol sulphuric acid method of Debois et al (1956) using pooled samples obtained from the inside pulp of the fruits.

Determination of crude protein: Crude protein was determined by semi micro-Kjeldahl technique (AOAC, 1990).

Determination of crude Fats: Crude fats were determined by soxhlet extraction, the method described by Association of Official Analytical Chemists (AOAC, 1990).

Determination of Reducing Sugars: Reducing sugar was determined by the modification of summer (1925), the 3,5-dinitrosalicuclic acid) DNS method.

Determination of Alpha-Amylase Assay: The alphaamylase assay was determined based on the iodometric method described by Wilson and Ingledew (1982).

Determination of Titratable acidity: The determined of titratable acidity was carried out as described by Ikenebomeh et al. (1986).

Determination of $\mathrm{pH}$ : The $\mathrm{pH}$ of the pooled pulp of the fruits was determined with $\mathrm{pH}$ metre (Gallenkamp Model 290mk).

Determination of Temperature: A sterile cork borer (ca $9 \mathrm{~mm}$ in diameter) was used in boring a hole at the upper end of each of the fruits of egusi about $2.5 \mathrm{~cm}$ from each of the deep vertical cuts. A sterile mercury bulb thermometer was inserted in each hole and sterile cotton wool was used to plug any opening at the point where the thermometer was inserted. The temperature of the rotting egusi fruits was determined at 24 hourly interval from the average readings of the thermometers.
RESULTS AND DISCUSSION

Laboratory rotting of egusi fruits was completed in 120 hours. At this stage, the pulp became soft and the seeds were easily extracted with fingers. The results of the changes in the composition of the pulp, alphaamylase activity and titratable acidity during the controlled rotting of egusi fruits are shown on Table 1. The composition of egusi fruits at the beginning of rotting ( 0 hour) showed that the moisture content was $82.04 \%$, carbohydrate $10.76 \%$, crude fats $6.85 \%$ and crude protein $0.39 \%$. The data reported by Purseglove (1991) indicated that the composition of egusi fruits by percent wet matter (\%WM) differs considerably from the values of some related edible members of the family. The moisture content of egusi fruit at 0 hour $(82.04 \%)$ is less than the value for wax or white gourd (Benincasa hispida Thumb) which is $96 \%$, water melon (Citrullus lunatum Thumb) $93.3 \%$ and melon (Cucumis Melon L) $92.1 \%$. The carbohydrate and fat contents of $10.76 \%$ and $6.85 \%$ respectively are higher than the values for those edible ones. The carbohydrate content of wax gourd, water melon and melon are 3.2, 5.3 and $6.2 \%$ respectively while the fat contents are melon $0.3 \%$, wax gourd and water melon $0.1 \%$ each. The protein content of egusi pulp $(0.39 \%)$ is fairly close to wax gourd $(0.4 \%)$, water melon and melon $0.5 \%$ each. Protein level increased gradually from $0.39 \%$ at 0 hours to $0.88 \%$ at 72 hours. At 96 hours it has increased to $4.38 \%$, and then fall to $1.14 \%$ at 120 hours. The changes could be attributed to microbial activities. Bacterial counts increased rapidly during the period from 24 hours, reached a peak at 72 hours and declined after 96 hours (Obeta and Abriba, 1994). The increase in protein level therefore corresponded to the period of rapid bacterial growth and activities which were accompanied by increase in $\mathrm{pH}$ and temperature. The level of water soluble carbohydrate gradually decreased from $10.76 \%$, at 0 hour to $0.35 \%$ at 120 hours. The rapid decrease in carbohydrate also corresponded to the period of large bacterial population and was accompanied by increase in protein level (Obeta and Abriba, 1994). This suggests a possible synthesis of proteins from carbohydrates. Bacteria are known to synthesize proteins from the products of carbohydrate metabolism (Rose, 1968). Moisture content also increased during the same period due to bacterial activities because in bacterial utilization of organic materials as energy sources, water is directly or indirectly produced as end products (Rose, 1968). The decrease in fat content between 0 hour and 120 hours is very small. This could be due to the inability of the participating microorganism to utilize egusi fruit fats or their preference for other substances in the fruit. Odunfa (1983) reported a very low lipase activity during the fermentation of boiled egusi seeds for the production of 'ogiri'. Between 0 hours and 24 hours, the level of reducing sugars decreased from $1.25 \mathrm{mg} / \mathrm{g}$ to $0.60 \mathrm{mg} / \mathrm{g}$, then increased to $1.01 \mathrm{mg} / \mathrm{g}$ at 48 hours, thereafter, there was a continuous decrease to the end of rotting. A similar observation has been reported by Odunfa (1983) during the fermentation of boiled egusi seeds. He attributed the initial decrease in reducing sugars to an initial bacterial populations which preferentially utilized the sugars. Considering the short period involved (24) hours, it is possible that bacterial which entered egusi 

CONTROLLED ROTTING OF EGUSI FRUITS

Period of Laboratory Rotting (h)

Moisture \% WM

Crude protein \% (Nx 6.25) WM

Crude fat \% WM

Water soluble $\mathrm{CHO} \% \mathrm{WM}$

Reducing sugars (mg g- WM)

Titratable acidity (mg lactic acid $\mathrm{g}^{-1} \mathrm{WM}$ )

Alpha-amylase activity (mg g-I WM)

$\mathrm{pH}$

Temperature

NOTE:

$$
\begin{array}{lll}
\text { WM } & = & \text { Wet matter } \\
\text { ND } & = & \text { Not detectable }
\end{array}
$$

Ambient temperature $=28^{\circ} \mathrm{C}$.

$\pm \quad=\quad$ Standard deviation.

$\mathrm{CHO}=$ Carbohydrate

\section{0}

$82.40 \pm 1.00$

$0.39 \pm 0.05$

$6.85 \pm 0.20$

$10.76 \pm 0.10$

$1.25 \pm 0.01$

$0.10 . \pm 0.01$

ND

$5.20 \pm 0.05$

$28.0 \pm 0.10$

24

$82.10 \pm 1.00$

48

$0.42 \pm 0.04$

$6.83 \pm 0.10$

$9.78 \pm 0.05$

$0.60 \pm 0.05$

$0.20 \pm 0.10$

$0.02 \pm 0.10$

$5.30 \pm 0.10$

$28.5 \pm 0.20$

$0.44 \pm 0.20$

$6.81 \pm 0.02$

$.50 \pm 0.01$

$1.01 \pm 0.01$

$0.20 \pm 0.10$

$0.80 \pm 0.50$

$5.50+0.05$

$29.0 \pm 0.50$

72

$83.10 \pm 0.10$

$0.88 \pm 0.01$

$6.80 \pm 0.05$

$3.25 \pm 0.50$

$0.40 \pm 0.02$

$0.30 \pm 0.05$

$0.05 \pm 0.10$

$6.20 \pm 0.05$

$29.0 \pm 0.50$
96

$84.90 \pm 0.05$

$4.38 \pm 0.10$

$6.75 \pm 0.05$

$1.75 \pm 0.03$

$0.25 \pm 0.03$

$0.50 \pm 0.05$

$0.30 \pm 0.02$

$6.50 \pm 0.10$

$30.0 \pm 0.25$
120

$85.00 \pm 0.05$

$1.14 \pm 0.04$

$6.72 \pm 0.01$

$0.35 \pm 0.02$

$0.25 \pm 0.02$

$0.70 \pm 0.02$

$0.02 \pm 0.01$

$6.70 \pm 0.10$

$30.0 \pm 0.25$ 
fruits by chanced inoculation were undergoing a sort of long lag phase which involved spore germination, increase in sizes of cells and syntheses of inducible enzymes compatible with the nature of the substrate. During this period, they would preferentially utilize reducing sugars which are readily absorbable and metabolisable. It will then be possible to explain the increase in reducing sugars after 24 hours as a result of the acquired ability of bacteria to utilize other carbohydrates, while the decrease between 72 hours and 96 hour could be due to bacterial population (Obeta and Abriba, 1994).

The steady increase in titratable acidity could be due to the activities of the participating bacteria especially Lactobacillus and Leuconostoc species which produce large amounts of acid from sugars (Fields et al 1981). Acid production has some marked effects on the activities of microorganisms. The activities of alphaamylase became detectable at 24 hours. It increased by 4 folds at 48 hours and there after declined till the end. This observation differs from the work of Odunfa (1983) in which alpha-amylase activity increased after 50 hours to 120 hours during the fermentation of boiled egusi seeds. The decline in alpha-amylase activity after 48 hours could be as a result of low level of utilization of starchy materials in the egusi seeds or preferential utilization of water soluble carbohydrates and reducing sugars. This work has therefore been able to establish the changes in the composition of the pulp, alphaamylase activity and titratable acidity brought about as a result of rotting, resulting in the softening of egusi pulp and therefore facilitating the easy removal of the seeds from the fruits.

\section{ACKNOWLEDGEMENT}

The authors are grateful to both the Technologists at the University of Calabar, Calabar, Nigeria and the University of Nigeria, Nsukka for their assistance.

\section{REFERENCES}

Achinewhu, S. C., 1983. Nutritive qualities of plant seeds; protein qualities of bread fruits (Artocarpus altilis) and climbing melon (Coloynthis vugaris) Nutrition Report International 25:643-647.

Achinewhu, S. C. and Ryley, 1986. The effects of fermentation on the thiamin, ribo flavin and niacin contents of melon seed (Citrulus vulgaris) and African oil bean seeds (Pentaclethra marcrophilla) Food Chemistry 20:243-250.

Akobundu, E. N. T., Cherry, J. P. and Simons, J. G., 1982. Chemical, functional and nutritional properties of egusi (Coloynthis citrullus L.) seed protein product. Journal of Food Sciences. 47:829-835.

AOAC, 1990. Association of Official Analytical Chemists. Official method of analysis. 15 ed. Arlington. AOAC International V.1. Pp.1117-1127.

Debois, M. Gilles, K. A. Hamilton, J. K. Rebers, P. A. and Smith, F. 1995. Colorimetric methods for the determination of sugars and related substances (Phenol-Sulphuric acid method). Journal of Analytical Chemistry. 28:350-352.
Fields, M. L, Hamad, A. M. and Smith, O. K. 1981. Natural lactic acid fermentation of corn meal. Journal of Food Sciences 46: 900-902.

Ikenebomeh, M. J., Kok, R. and Ingram, J. M., 1986. Processing and fermentation of the African locust beans (Parkia filicoides) to produce daddawa. Journal of Food Sciences and Agriculture. 37: 273-282.

Obeta, J. A. N. and Abriba, C., 1994. Microbiology of controlled rotting of egusi fruit (Colocynthis citrullus $L$ ) for the harvesting of the seeds. World Journal of Microbiology and Biotechnology. 19:634-636.

Obiora, J. O. and King, R. D., 1984. Thermal Transitions of melon proteins. Journal of Food Chemistry. 13:309-375.

Odunfa, S. A., 1982. Microbiology of Vitamin B and Biotin in some Nigerian fermented foods. Journals of Food Chemistry 10: 19-36.

Odunfa, S. A., 1983. Bilchemical changes during the production of 'ogiri'a fermented melon (Citrullus vulgaris schrad) product. Qualitas Plantarum Plant Food for Human Nutrition 32:3-10.

Onuora, J. O. and King, R. D., 1984. Melon seed flour: composition and factors affecting the extractability of nitrogenous constitutions. Lebensm Wiss U Technology. 16:162-166.

Oyenuga, V. A., 1968. Nigeria's Foods and Feedstuffs: their chemistry and nutritive values $3^{\text {rd }}$ ed Pp 8789 Ibadan: Ibadan University Press.

Oyenuga, V. A. and Fetuga, B. L., 1975. Some aspect of the biochemistry and nutritive values of the water melon seeds (Citrullus vulgaris schrad) Journal of the Science of Food and Agriculture. 26: 843-854.

Oyolu, C., 1977. A quantitative and qualitative study of egusi seed types in egusi (Colocynthis citriullus L.) Tropical Science 19:55-61.

Purseglove, J. W., 1991. Dicotyledons in Tropical Crops. $3^{\text {rd }}$ end. Pp 100-136. Singapore. Longmans.

Rose, A. H., 1968. Utilisation of organic materials by microorganism in: Chemical Microbiology $2^{\text {nd }}$ ed Pp 120-127. London Bulterworths. 33Pp.

Standford, W. and Oke, D. L., 1977. Protein isolates from lesser known oil seeds from Nigeria. Nutrition Reports International. 16: 813-820.

Summer, J. B. 1925. Estimation of Reducing Sugars with 3,5-dinitrosalicyclic Aids (DNS). Journal of Biological Chemistry. 62: 287-290.

Wilson, J. J. and Ingledew, W. M., 1982. Isolation and Characterization of Schwanniomyces alluves amyloytic enzymes. Journal of Applied Environmental Microbiology. 44 (2): 301-307. 
